\title{
Association of Enterobacter cloacae with Rhizome Rot of Edible Ginger in Hawaii
}

\author{
K. A. Nishijima, Pacific Basin Agricultural Research Center (PBARC), USDA-ARS, P.O. Box 4459, Hilo, HI \\ 96720; A. M. Alvarez, University of Hawaii-Manoa, Honolulu 96822; P. R. Hepperly, PBARC, USDA-ARS, Hilo, \\ HI; M. H. Shintaku, University of Hawaii-Hilo, College of Agriculture, Forestry \& Natural Resource Management, \\ Hilo 96720; L. M. Keith, PBARC, USDA-ARS, Hilo, HI; D. M. Sato and B. C. Bushe, University of Hawaii- \\ Cooperative Extension Service, Hilo 96720; and J. W. Armstrong and F. T. Zee, PBARC, USDA-ARS, Hilo, HI
}

\begin{abstract}
Nishijima, K. A., Alvarez, A. M., Hepperly, P. R., Shintaku, M. H., Keith, L. M., Sato, D. M., Bushe, B. C., Armstrong, J. W., and Zee, F. T. 2004. Association of Enterobacter cloacae with rhizome rot of edible ginger in Hawaii. Plant Dis. 88:1318-1327.

Edible ginger is a popular spice crop that is grown in Hawaii primarily for the fresh market, and as such, rhizome quality is of paramount importance. In our studies, a Gram-negative, facultative anaerobic, rod-shaped bacterium was consistently isolated from decayed as well as symptomless ginger rhizomes. The bacterium was identified as Enterobacter cloacae by biochemical assays and $16 \mathrm{~S}$ rDNA sequence analysis. Rot symptoms, which usually occurred in the central cylinder of the rhizome, were characterized by yellowish-brown to brown discolored tissue and firm to spongy texture. In inoculation experiments, ginger strains of $E$. cloacae produced basal stem and root rot, with foliar chlorosis and necrosis in tissue-cultured ginger plantlets, and discolored and spongy tissue in mature ginger rhizome slices and whole segments. In other hosts, ginger strains of $E$. cloacae caused internal yellowing of ripe papaya fruit and internal rot of onion bulbs. All strains that caused symptoms in inoculated plants were reisolated and identified as E. cloacae. Our studies suggest that E. cloacae can exist as an endophyte of ginger rhizomes, and under conditions that are favorable for bacterial growth, or host susceptibility, including maturity of tissues, rhizome rot may occur. Rhizome quality may be impacted by the presence of $E$. cloacae under conditions such as high temperature, high relative humidity, and low oxygen atmosphere that may affect the development of decay, and such conditions should be avoided during postharvest handling and storage. The association of E. cloacae with a rhizome rot of ginger is a new finding.
\end{abstract}

Additional keywords: bacterial wilt, Enterobacteriaceae, extracellular polysaccharide (EPS), modified atmosphere packaging, Ralstonia solanacearum

Edible ginger (Zingiber officinale Roscoe) is a popular spice crop grown in Hawaii, primarily on the island of Hawaii, with annual production at approximately 6.35 million $\mathrm{kg}$ (14 million $\mathrm{lbs})$ and value at about $\$ 4.3$ million (20). Bacterial wilt disease, caused by Ralstonia solanacearum (Smith) Yabuuchi, is the most devastating and destructive disease of ginger. It is characterized by wilt, eventual death of ginger plants, and rhizomes with reduced quality due to discoloration and/or rotted tissue $(14,37)$. Beginning in 2001, we attempted to isolate and collect $R$. solanacearum strains from bacterial wilt-infected

Corresponding author: K. A. Nishijima

E-mail: knishijima@pbarc.ars.usda.gov

Current address of P. R. Hepperly: The Rodale Institute, 611 Siegfriedale Road, Kutztown, PA 19530.

Accepted for publication 17 July 2004

\section{Publication no. D-2004-1013-01R}

This article is in the public domain and not copyrightable. It may be freely reprinted with customary crediting of the source. The American Phytopathological Society, 2004. field plants grown on the Hamakua coast of the island of Hawaii. However, a facultative anaerobic, gram negative, rodshaped bacterium was repeatedly isolated along with the targeted bacteria. The bacterium was later identified as Enterobacter cloacae (Jordan) Hormaeche \& Edwards. Strains of E. cloacae were also isolated from symptomless ginger rhizomes obtained from local supermarkets.

E. cloacae is the most frequently isolated Enterobacter species from man and animals (28) and is commonly found on or in plants, insects, and many sources in our environment (e.g., water, sewage, soil, freshly harvested vegetables) $(5,15,18,19$, $23,28,30,31)$. In addition to being a human pathogen (31), E. cloacae is a pathogen of plants. Examples of plant hosts include elm trees $(7,25)$, coconut $(10)$, orchid (36), corn (29), onion bulb $(4,8,33)$, apple (30), papaya fruit $(26,27)$, and mung bean sprouts (38).

We report on the identification and characterization of E. cloacae strains isolated from ginger rhizomes, their pathogenic responses on ginger and other hosts, and discuss some of the factors that may trigger disease development in ginger.

\section{MATERIALS AND METHODS}

Isolations from ginger rhizomes obtained from field and supermarket. Bacterial strains were isolated from 80 ginger plants with bacterial wilt symptoms collected from two ginger farms located on the Hamakua coast of the island of Hawaii in 2001 and 2002, and from 20 symptomless rhizomes purchased from a supermarket in Hilo in 2001. Ginger rhizomes from the field were rinsed in tap water to remove excessive debris, disinfected 5 min in $0.5 \%$ sodium hypochlorite, once in the field and a second time in the laboratory, then rinsed in sterile distilled water (SDW) for $1 \mathrm{~min}$, drained, and air-dried before aseptically cross-sectioning the rhizomes and excising approximately $3 \mathrm{~mm}^{3}$ tissue sections from the endodermal ring or the central cylinder. The tissue sections were soaked in tubes of 3 to $5 \mathrm{ml}$ of SDW for at least $1 \mathrm{~h}$ before streaking one to two loopsful of each suspension onto PT-M2 agar medium, a modified (no salt) agar version of peptone-yeast extract-medium (ATCC Medium 1366) (2) containing $1.8 \%$ bactoagar, $1 \%$ peptone, $0.5 \%$ yeast extract, and $0.001 \%$ triphenyltetrazolium chloride (TTC; Sigma Chemical Co., St. Louis, MO; added to sterile, molten agar prior to pouring). Plates were incubated at room temperature $\left(22^{\circ} \mathrm{C}\right)$ or $30^{\circ} \mathrm{C}$, and single colonies were isolated and restreaked at least two consecutive times to purify the strains. Stock cultures were stored in SDW in test tubes at $20^{\circ} \mathrm{C}$ or at room temperature. Strains selected for long-term storage were stored in $15 \%$ glycerol at minus $80^{\circ} \mathrm{C}$.

Separation of E. cloacae and R. solanacearum was initially difficult on Kelman's medium (17) with reduced TTC $(0.001 \%)$ because of high amounts of bacterial extracellular polysaccharide (EPS) produced by $R$. solanacearum. The PT-M2 medium was used in isolation procedures to reduce EPS production of $R$. solanacearum. Aerobic strains, including putative $R$. solanacearum, were grown on PT-M2 at room temperature. E. cloacae and other facultative anaerobes were grown at $30^{\circ} \mathrm{C}$ on PT-M4 agar medium, (PT-M2 plus $0.25 \%$ sodium chloride), which was more favorable for growth.

Identification and characterization of bacterial strains. Purified cultures were initially characterized using Difco oxida- 
tive-fermentative (OF) basal medium with $1 \%$ glucose as a carbohydrate source (13). The inoculated medium was layered with sterile mineral oil to produce anaerobic conditions, and the tubes were incubated at $30^{\circ} \mathrm{C}$ for $24 \mathrm{~h}$. Facultative anaerobes were identified as Enterobacter sp. or other members of the Enterobacteriaceae using API 20E strips (bioMerieux, Inc., USA office, Durham, NC) incubated at $30^{\circ} \mathrm{C}$ for 18 to $24 \mathrm{~h}$. Selected strains were further characterized and compared with an $E$. cloacae strain from fruit fly (27) by various tests that included: (i) phenylalanine deaminase (9); (ii) acid production from filter-sterilized, $10 \%$ solutions of glucose, cellobiose, lactose, or $\alpha$-methyl-glucoside incorporated into Difco OF basal medium (carbohydrate final concentration, 1\%) under anaerobic conditions; (iii) growth on several media including yeast extractdextrose-calcium carbonate medium (YDC) (35) and Miller-Schroth medium (MS) (22); and (iv) pectate degradation with modified crystal violet-pectate medium (CVP) (32). The tests were repeated one or more times to confirm strain identification. Cell measurements of selected bacterial strains were determined using a Leica Laborlux D light microscope on Gramstained cells from 3-day-old cultures.

Identification of Enterobacter species was confirmed using PCR amplification from total DNA using the Y1 and Y2 primers that are complementary to highly conserved sequences within the $16 \mathrm{~S}$ rDNA of the alpha proteobacteria (39). Following purification and sequencing, a NCBI BLASTN search (1) was conducted on an approximately 300-bp sequence. The type strain for E. cloacae, ATCC 13047, was included as a positive control.

Pathogenicity studies on bacterial strains. Pathogenicity studies were conducted using strains B193-3 and KN1-19 isolated from rotted ginger rhizomes from the island of Hawaii, and E. cloacae strain Dd-18 isolated from the oriental fruit fly Bactrocera dorsalis (Hendel) and characterized in earlier studies $(15,27)$.

All inoculum for this study was prepared from cultures grown on PT-M4 agar medium at $30^{\circ} \mathrm{C}$ for 3 to 5 days. A bacterial suspension for each strain was prepared by scraping cells from individual cultures into 15 to $20 \mathrm{ml}$ of SDW and adjusting to optical density (OD) approximately $0.5 A_{600}$ using a Turner SP-830 spectrophotometer, which was equivalent to $10^{8}$ to $10^{9} \mathrm{CFU} / \mathrm{ml}$. SDW was used as a control.

Inoculation tests were performed on: (i) aseptic tissue-cultured ginger plantlets in test tubes; (ii) ginger rhizome slices in petri dishes; (iii) ginger rhizome segments stored under low oxygen (vacuum-sealed bags) or aerobic (without vacuum-sealed bags) conditions; (iv) young ginger plants grown in pots in the greenhouse; (v) papaya fruit; and (vi) yellow onion bulbs. (i) Inoculation of ginger plantlets in test tubes. Tissue-cultured ginger plantlets, grown in test tubes $(25 \mathrm{~mm}$ diameter $\times 150 \mathrm{~mm}$ long) on Murashige and Skoog agar medium (24), were obtained from the Pacific Basin Tropical Plant Genetic Resource Management Unit (USDA-ARSPBARC, Hilo, HI). Each test tube contained a single plantlet (approximately 7 to $10 \mathrm{~cm}$ high) that was inoculated either with $0.5 \mathrm{ml}$ of bacterial suspension (described earlier) or $0.5 \mathrm{ml}$ of SDW (control). To determine the effect of wounding on disease development, half of the plantlets for each bacterial or control treatment were wounded by nicking the root area with a sterile scalpel; the other half of the plantlets were not wounded. Four plantlets for each bacterial or control treatment were placed randomly in test tube racks and incubated at $30^{\circ} \mathrm{C}$ in a continuously illuminated incubator (fluorescent cool, daylight, 15W, VWR 2020). Four days after inoculation, and every 2 to 4 days thereafter for approximately 14 days, individual plantlets were evaluated for foliar and rhizome/root symptoms (chlorosis or necrosis, and discoloration or rot, respectively) using a disease severity rating scale of 1 to 5 where $1=$ no symptoms, $2=$ slight (up to 25\%) foliar and/or rhizome/root symptoms, 3 = moderate (up to $50 \%$ ) foliar and/or rhizome/root symptoms, $4=$ severe (up to $75 \%$ ) foliar and/or rhizome/root symptoms, and $5=$ dead plantlet. The experimental design was a randomized complete block, split plot with replicates consisting of two to four plantlets and where the main plot was inoculation method and the subplot was bacterial treatments. The experiment was conducted four times, twice with both wounded and nonwounded plantlets, and twice with only nonwounded plantlets. Disease severity ratings were performed on three experiments (experiments 2, 3, and 4).

(ii) Ginger rhizome slice inoculations. Ginger rhizomes ('Chinese' type, a commercial variety characterized by light yellow flesh and a mildly pungent flavor) of two maturities were used: (i) immature ginger rhizomes obtained from 5- to 7month-old plants initiated from tissue culture, transplanted into Sunshine mix $(90 \%$ peat moss) and volcanic cinder media (1:1), and grown in a greenhouse under ambient conditions, and (ii) mature, fieldgrown rhizomes purchased from a local produce packinghouse. The rhizomes were maintained in aerated fiberboard cartons at room temperature $\left(22^{\circ} \mathrm{C}\right)$ until use.

The rhizomes were washed in tap water, air-dried, and then cross-sectioned into approximately 3-mm-thick slices (crosssection lengths of at least $2 \mathrm{~cm}$ ) with a flame-sterilized knife. Each slice was briefly flamed on both surfaces and rehydrated by dipping in SDW. Four slices were placed single-layered onto sterile, SDW-moistened filter paper in a petri dish
(100 mm diameter). Rhizome slices of each maturity group were inoculated with bacterial suspension or with SDW (control).

Two inoculation methods were used in separate experiments. In the first method, sterilized toothpicks coated at the tip with bacterial culture or SDW were stabinoculated into each ginger slice at the central cylinder or at the outer cortex (endodermal layer). In the second method, ginger slices were puncture-wounded, and $100 \mu \mathrm{l}$ of SDW or bacterial suspension at approximately $10^{7}, 10^{8}$, and $10^{9} \mathrm{CFU} / \mathrm{ml}$ (as determined by viable counts of serial dilutions of the initial suspension at $\mathrm{OD}=$ $\left.0.5 A_{600}\right)$ was pipette-inoculated into the center of each slice. Four slices of each rhizome maturity group were inoculated at each of the inoculation positions in the first experiment. Four slices of each rhizome maturity group were inoculated with each of the bacterial concentrations or SDW (control) treatments in the second experiment. The inoculated slices in petri dishes were incubated in plastic Ziploc storage bags at $30^{\circ} \mathrm{C}$ until symptoms were observed, after approximately 12 to 14 days, and then were evaluated. Ginger slices were rated for severity of rot symptoms based on a scale of 1 to 5 where $1=$ healthy tissue, 2 = slight (up to $25 \%$ ) rot (slight discoloration), $3=$ moderate (up to $50 \%$ ) rot (discoloration and tissue breakdown), $4=$ severe rot (50 to $75 \%$ of slice affected), and $5=$ complete rot (up to entire slice affected).

The experimental design was a randomized complete block, split-split plot with replicates consisting of four slices and where the main plot was rhizome maturity, the subplot was inoculation site or bacterial concentration (first or second experiment, respectively), and the sub-subplot was bacterial treatments. The first experiment was conducted three times and the second experiment twice.

(iii) Inoculation of ginger rhizome segments. Immature to recently matured ginger rhizomes ('Chinese' type) were purchased from a farmers' market in Hilo. Rhizomes were washed in tap water, surface disinfected in $0.5 \%$ sodium hypochlorite for $3 \mathrm{~min}$, rinsed in distilled water, then drained and air-dried before cutting into segments (at least $9 \mathrm{~cm}$ lengths, $82 \mathrm{~g}$ mean weight) with a sterilized knife. The cut surfaces were flamed to "seal" the wound tissue. Each rhizome segment was injected with approximately $0.3 \mathrm{ml}$ of bacterial suspension $\left(10^{8}\right.$ to $\left.10^{9} \mathrm{CFU} / \mathrm{ml}\right)$ at one to three selected sites, depending on the rhizome size, using a sterile $3 \mathrm{cc}$ tuberculin syringe fitted with a 23 -gauge needle. The inoculated sites were then covered with autoclavable tape to prevent crosscontamination. Controls were treated similarly with SDW. At least five sites were inoculated for each of two sets of segments for each bacterial or SDW treatment. One 
set of inoculated rhizome segments of the same treatment was vacuum-sealed, one to three segments at a time, in sealing bags using a Mini Vacuum/Professional packaging machine (Minipack-America, same as Minipack-Torre - Italy), creating low oxygen storage conditions. The second set of inoculated rhizomes was stored under aerobic conditions (not in bags). All rhizomes were placed in fiberboard cartons, incubated at $30^{\circ} \mathrm{C}$ for 6 to 8 days, then cut and evaluated for discoloration and other rot symptoms. The experimental design was a randomized complete block, split plot with replicates consisting of at least five inoculations and where the main plot was storage conditions (low oxygen or aerobic) and the subplot was bacterial treatments. The experiment was conducted three times.

(iv) Inoculation of ginger plants in greenhouse. Tissue culture-initiated ginger plants were grown in 15 -cm-diameter plastic pots containing Sunshine potting soil (Sun Gro Horticulture Canada, Ltd. of

Table 1. Biochemical and physiological characteristics of Enterobacter asburiae, E. cloacae strain from oriental fruit fly (Dd-18), and strains B193-3 and KN1-19 from ginger rhizome

\begin{tabular}{|c|c|c|c|c|c|}
\hline Characteristic & E. asburiae ${ }^{\mathrm{r}}$ & E. cloacae $^{\mathrm{s}}$ & $\begin{array}{l}\text { Strain Dd-18 } \\
\text { E. }_{\text {cloacae }}\end{array}$ & $\begin{array}{l}\text { Strain } \\
\text { B193-3 }\end{array}$ & $\begin{array}{l}\text { Strain } \\
\text { KN1-19 }\end{array}$ \\
\hline \multicolumn{6}{|l|}{ API 20E tests } \\
\hline$\beta$-Galactosidase & $+^{\mathrm{u}}$ & + & + & + & + \\
\hline Arginine dihydrolase & $\mathrm{V}^{\mathrm{u}}$ & + & V & + & + \\
\hline Lysine decarboxylase & $-^{\mathrm{u}}$ & - & - & - & - \\
\hline Ornithine decarboxylase & + & + & + & + & + \\
\hline Citrate utilization & + & + & + & + & + \\
\hline Hydrogen sulfide & - & - & - & - & - \\
\hline Urease & + & - & - & - & - \\
\hline Tryptophan deaminase & - & - & - & - & - \\
\hline Indole & - & - & - & - & - \\
\hline Voges-Proskauer & - & + & + & + & + \\
\hline Gelatin liquefaction & - & + & - & - & - \\
\hline \multicolumn{6}{|l|}{ Acid from } \\
\hline Glucose & + & + & + & + & + \\
\hline Mannitol & + & + & + & + & + \\
\hline Inositol & - & - & - & - & - \\
\hline Sorbitol & + & + & + & + & + \\
\hline Rhamnose & - & + & + & + & + \\
\hline Sucrose & + & + & + & + & + \\
\hline Melibiose & - & + & + & + & + \\
\hline Amygdalin & + & + & + & + & + \\
\hline Arabinose & + & + & + & + & + \\
\hline Oxidase & - & - & - & - & - \\
\hline Nitrate reduction & + & + & + & + & + \\
\hline Catalase $^{\mathrm{v}}$ & + & + & + & $\mathrm{W}^{\mathrm{u}}$ & + \\
\hline \multicolumn{6}{|l|}{ Other tests } \\
\hline Anaerobic growth ${ }^{\mathrm{w}}$ & + & + & + & + & + \\
\hline Phenylalanine deaminase $\mathrm{x}^{\mathrm{x}}$ & - & - & - & - & - \\
\hline Pectate degradation ${ }^{\mathrm{y}}$ & - & - & - & - & - \\
\hline \multicolumn{6}{|l|}{ Acid from ${ }^{\mathrm{Z}}$} \\
\hline Cellobiose & + & + & + & + & + \\
\hline Lactose & + & + & + & + & + \\
\hline$\alpha$-Methyl-D-glucoside & + & + & + & + & + \\
\hline
\end{tabular}

${ }^{\mathrm{r}}$ Data from Brenner et al., 1986 (6).

s Data from Richard, 1984 (28).

${ }^{\mathrm{t}}$ Same strain characterized in a previous study (27).

${ }^{\mathrm{u}}+=$ positive reactions; $-=$ negative reactions; $\mathrm{W}=$ weak reactions; $\mathrm{V}=$ variable results.

${ }^{\mathrm{v}}$ Results by using hydrogen peroxide, USP $3 \%$.

${ }^{w}$ Difco OF basal medium with $1 \%$ glucose (final concentration), inoculated and layered with sterile mineral oil.

${ }^{x}$ Method of Ewing et al., 1957 (9).

${ }^{y}$ Method using modified crystal violet-pectate (CVP) medium (32).

${ }^{z}$ Difco OF basal medium with $1 \%$ carbohydrate source (final concentration). $41^{\circ} \mathrm{C}$ ) and relative humidity (34 to $100 \%$ ). Plants were watered daily by an automated irrigation system, and Nutricote fertilizer (17 g) was applied as needed. Treatment replicates consisted of four plants that were arranged on a greenhouse bench in a completely randomized block design, and foliar symptoms were rated weekly using the 1 to 5 disease rating scale. The experiment was conducted three times.

(v) Papaya fruit inoculations. Onehalf- to three-quarter-ripe papaya fruit (Carica papaya L.) of three cultivars ('Kapoho Solo', 'Rainbow', and 'Sun Up') were obtained from commercial sources on the island of Hawaii. 'Rainbow' is the F1 hybrid resulting from a cross between 'Kapoho Solo' and the transgenic cultivar 'Sun Up'. Fruits were washed in tap water, air-dried, and surface disinfected by wiping with $70 \%$ ethanol. The fruits were inoculated at randomized sites along the longitudinal transect. Each site was injected with $0.5 \mathrm{ml}$ of a bacterial suspension $\left(10^{8}\right.$ to $\left.10^{9} \mathrm{CFU} / \mathrm{ml}\right)$ or SDW, using a sterile $3 \mathrm{cc}$ tuberculin syringe fitted with a 23 gauge needle, then covered with autoclavable tape. Sixteen to 23 'Kapoho Solo', 20 'Rainbow', or 20 'Sun Up' fruits were inoculated each time in repeated, separate experiments for each cultivar. Fruit were incubated in cartons at 23 to $28^{\circ} \mathrm{C}$ until ripe (4 to 5 days), then evaluated for internal yellowing symptoms (yellow discolored flesh and rotting odor) (27). The experimental design for 'Kapoho Solo' and 'Rainbow' fruit was a randomized complete block design (two experiments) or a randomized incomplete block design (one experiment) where each fruit was inoculated with all bacterial treatments (complete block) or with at least two of the three E. cloacae strains (incomplete block). Strains B193-3 and Dd-18 were utilized in all three experiments, and data were pooled for analysis of each cultivar. The experimental design for 'Sun Up' fruit was a randomized complete block design where each fruit was inoculated with all bacterial treatments. The experiment was conducted two times. Replicates consisted of the number of fruit inoculated in each experiment for each cultivar, as described.

(vi) Onion bulb inoculations. Commercial, grade A, mature yellow onion (Allium cepa L.) bulbs (approximately 64 $\mathrm{mm}$ diameter) were obtained from a local supermarket. After removing the outer protective scale leaf and two layers of fleshy scale leaf, the bulbs were washed in tap water, air-dried, and then inoculated. Each onion bulb was injected at the stemend with $0.5 \mathrm{ml}$ of bacterial suspension $\left(10^{9} \mathrm{CFU} / \mathrm{ml}\right)$ or SDW, using a sterile 10 cc syringe fitted with a 22-gauge needle. Four to five bulbs were injected for each treatment, individually placed in plastic storage bags (Ziploc), and incubated at $30^{\circ} \mathrm{C}$ in a Fisher Isotemp LowTemperature incubator (Fisher Scientific, 
Pittsburgh, PA). After 11 to 18 days, the bulbs were cut transversely through the center and evaluated for incidence and severity of rot symptoms using a 1 to 5 rating scale where $1=$ healthy, $2=$ slight (up to $25 \%$ ) rot (slight discolored or flaccid tissue), 3 = moderate (up to $50 \%$ ) rot (internal tissue generally discolored and flaccid), $4=$ severe $\operatorname{rot}$ ( 50 to $75 \%$ of bulb affected), and $5=$ complete rot (up to entire bulb affected) (4,33). The experimental design was a randomized complete block with replicates consisting of four to five bulbs. The experiment was conducted two times.

Reisolation of inoculated bacterial strains. Reisolation and identification using API 20E strips of the two ginger strains and the fruit fly strain from symptomatic tissue of inoculated plants were performed to fulfill Koch's postulates and conducted according to methods described earlier, with some modifications. Tissuecultured ginger plantlets were rinsed in distilled water to remove agar from roots, and excised tissue pieces from all reiso- lated plants (ginger, papaya, onion) were disinfected for 2 min in $0.5 \%$ sodium hypochlorite and drained on clean Kimwipes tissue. The excised sections were placed in tubes of SDW, macerated aseptically with a sterile glass rod, and allowed to soak $1 \mathrm{~h}$ before streaking the liquid suspension on PT-M2 agar medium. Isolations from selected plants inoculated with SDW were similarly performed.

Data analysis. Data were analyzed for main effects, or for main and interactive effects (factorial analysis), by the general linear models (GLM) procedure of SAS, version 8.0 (SAS Institute, Inc., Cary, NC). Analyses were performed on nontransformed data except for arcsine-square root transformations that were performed before analysis on proportion of infected onion bulbs according to protocols described in Snedecor \& Cochran (34). Means separation (where appropriate) were performed by pairwise comparisons of means by the $t$ test of the least squares means (LSMeans) option of GLM, or by Fisher's protected LSD test, at $P=0.05$, using version 8.0 of SAS statistical software.

\section{RESULTS}

Bacterial strains: isolation and symptoms. Rhizomes with rot symptoms attributed to E. cloacae or $R$. solanacearum were not easily distinguishable, and both species were repeatedly isolated from ginger plants with foliar symptoms $(14,37)$ of bacterial wilt disease. PT-M2 medium facilitated the isolation and separation of both species by reducing EPS production by $R$. solanacearum.

The presence and activity of E. cloacae in ginger rhizomes was associated with a range of symptoms from mild watersoaking, to dark yellow, or tan-brown discoloration in the central cylinder of rhizomes that appeared externally healthy. Severe symptoms included dark brown discoloration of the central cylinder, collapsed tissue, and a foul or putrid odor occasionally emitted from rhizomes that were rotted or spongy in texture and possibly produced in association with other bacteria.

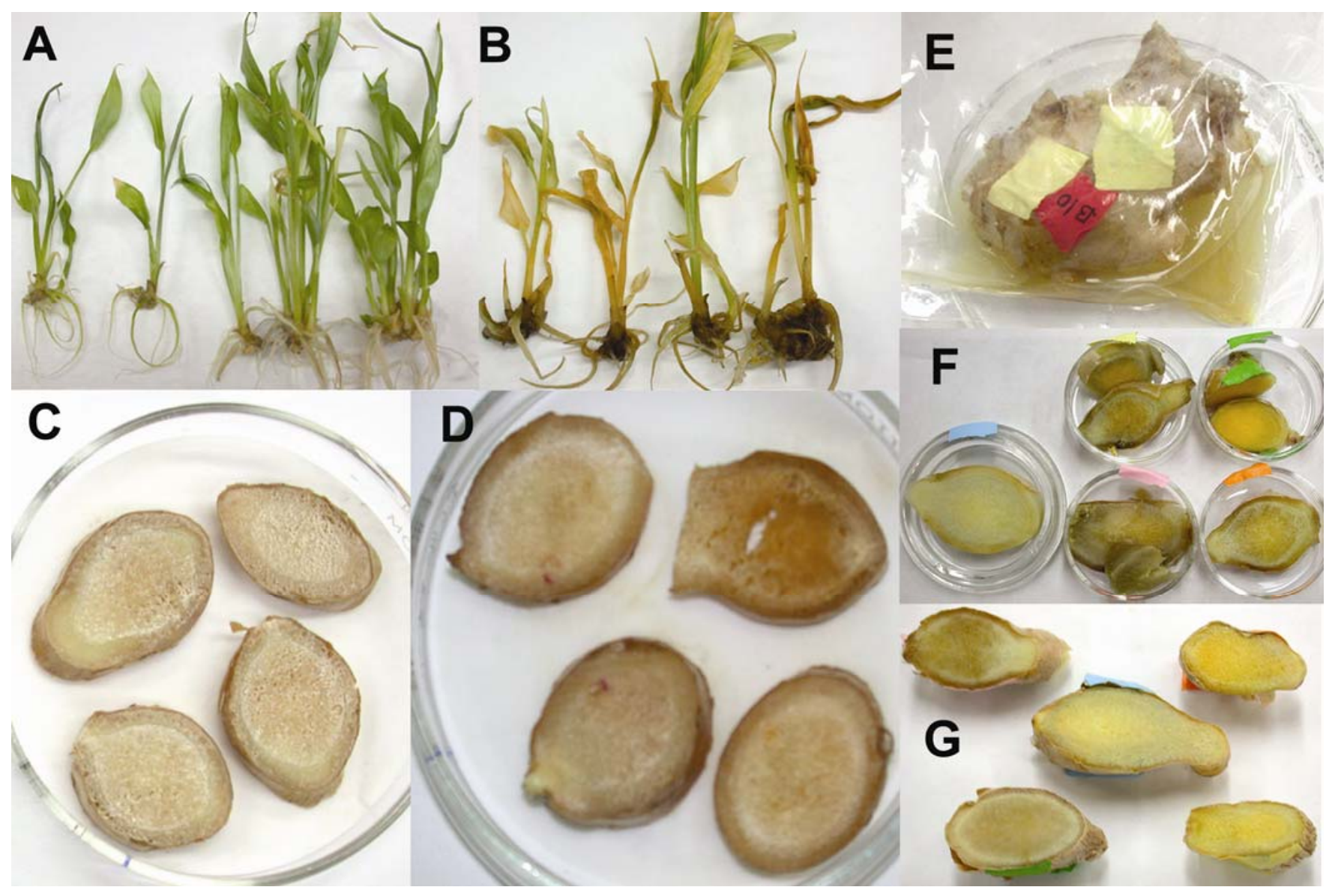

Fig. 1. Symptoms produced by Enterobacter cloacae on ginger plantlets, rhizome slices and whole rhizome segments. A and B, Tissue-cultured ginger plantlets in test tubes at $30^{\circ} \mathrm{C}, 14$ days after inoculation. A, Healthy plantlets that were inoculated with sterile distilled water (SDW). B, Foliar symptoms (dark yellow chlorosis, 'burning' necrosis) and basal root and stem rot on plantlets inoculated with B193-3. C and D, Mature ginger rhizome slices incubated in petri dishes after 12 to 14 days at $30^{\circ} \mathrm{C}$. C, Healthy ginger slices that were inoculated with SDW. D, Mild rot symptoms (discoloration, water-soaking) on ginger slices inoculated with B193-3. E to G, Whole ginger rhizome segments after 6 to 8 days at $30^{\circ} \mathrm{C}$ in vacuum-sealed bags (E, F) or not in bags (G). E, Spongy and collapsed tissue of rhizome segment inoculated with KN1-19. F, Healthy tissue of whole ginger rhizome segment treated with SDW (bottom row, far left), and discolored or rotted tissue of rhizome segments inoculated with B193-3 (bottom row, center and right), KN1-19 (top row, left), and Dd-18 (top row, right). G, Healthy tissue of whole rhizome segment inoculated with SDW (center row) and discolored tissue of rhizome segments inoculated with B193-3 (top row, left and right), KN1-19 (bottom row, right), and Dd18 (bottom row, left). 
Foliar symptoms associated with E. cloacae based on laboratory and field observations were characterized by distinct, dark yellow chlorosis with amber-colored necrosis at margins or tips, and dieback symptoms. Wilt symptoms in the field occurred in association with $R$. solanacearum.

Rhizomes collected from farms and supermarket. Fourteen facultatively anaerobic strains with colony characteristics resembling Enterobacter sp. were isolated from 80 wilted ginger plants collected from two farms on the Hamakua coast. Eight similar strains were isolated from 20 symptomless ginger rhizomes purchased from a Hilo supermarket. The strains were presumptively identified to the genus Enterobacter sp. Four representative strains were identified as E. cloacae using API 20E strips (bioMerieux) after 18 to $24 \mathrm{~h}$ incubation at $30^{\circ} \mathrm{C}$.

Characterization of strains. Biochemical and physiological characteristics of two representative strains from diseased ginger rhizomes (B193-3 and KN1-19) were similar to those of the fruit fly strain (Dd-18) (Table 1). The strains were a $95.2 \%$ identification match (based on biochemical profile) for E. cloacae on API 20E strips. All three strains were gram negative, catalasepositive, oxidase-negative, facultatively anaerobic, negative for pectate degradation and phenylalanine deaminase, and matched the biochemical and physiological characters described for E. cloacae (28), except for a negative reaction for liquefaction of gelatin (Table 1). The three strains differed from $E$. asburiae in tests for urease, Voges-Proskauer reaction, and acid production from rhamnose and melibiose (Table 1). The referenced characterization of E. asburiae (6) was positive for urease and negative for the other biochemical tests. E. asburiae and fruit fly strain Dd-18 were variable for the arginine dihydrolase reaction.

Table 2. Description of symptoms resulting from artificial inoculation of various hosts with Enterobacter cloacae strains B193-3 and KN1-19 (ginger) and Dd-18 (fruit fly)

\begin{tabular}{|c|c|}
\hline Host & Symptoms \\
\hline \multicolumn{2}{|l|}{ Ginger } \\
\hline \multirow{4}{*}{$\begin{array}{l}\text { Tissue-cultured plantlets } \\
\text { in test tubes, } 30^{\circ} \mathrm{C}\end{array}$} & Rhizome: Brown discoloration; rot (ginger strains) \\
\hline & Foliage: \\
\hline & $\begin{array}{l}\text { Dark yellow chlorosis; amber (“burning") necrosis (ginger } \\
\text { strains); }\end{array}$ \\
\hline & Weak or no symptoms (fruit fly strain) \\
\hline $\begin{array}{l}\text { Tissue-cultured plants } \\
\text { in } 15 \mathrm{~cm} \text { pots, greenhouse }\end{array}$ & No rhizome or foliar symptoms (all strains) \\
\hline $\begin{array}{l}\text { Rhizome slices } \\
\text { in petri dishes, } 30^{\circ} \mathrm{C}\end{array}$ & $\begin{array}{l}\text { Water-soaked, tan-yellow central cylinder; spongy to } \\
\text { collapsed tissue (ginger strains) }\end{array}$ \\
\hline \multicolumn{2}{|l|}{ Rhizome segments } \\
\hline in vacuum-sealed bags, $30^{\circ} \mathrm{C}$ & $\begin{array}{l}\text { Water-soaked, tan-brown to gray central cylinder, or } \\
\text { completely dark to "fluorescent" yellow; spongy to } \\
\text { collapsed tissue; gas production; foul odor (all strains) }\end{array}$ \\
\hline not in bags, $30^{\circ} \mathrm{C}$ & Less severe symptoms; no gas; no foul odor (all strains) \\
\hline \multicolumn{2}{|l|}{ Papaya fruit } \\
\hline 'Kapoho Solo', 23 to $28^{\circ} \mathrm{C}$ & $\begin{array}{l}\text { Internal yellowing (bright to "fluorescent" yellow; rot; foul } \\
\text { odor) (all strains) }\end{array}$ \\
\hline \multicolumn{2}{|r|}{ (1) } \\
\hline Yellow onion, $30^{\circ} \mathrm{C}$ & $\begin{array}{l}\text { Internal rot (tan to dark brown; flaccid internal scales) (all } \\
\text { strains) }\end{array}$ \\
\hline
\end{tabular}

and incidence of dead plants. Results for the plantlets inoculated with ginger strains of E. cloacae were significantly different $(P<0.05)$ from SDW control plantlets. When inoculated with B193-3 or KN1-19 strains, 96 to $100 \%$ of the plantlets developed foliar and/or root symptoms with a mean disease severity rating of 4.1 to 4.3 , and 38 to $63 \%$ of the plantlets were dead after 14 days (Table 3 ). Tissue-cultured plantlets inoculated with fruit fly strain Dd-18 did not result in any plantlet deaths, although $33 \%$ of the plantlets developed foliar and/or root symptoms with a mean disease severity rating of 1.44 that was not significantly different $(P>0.05)$ from the SDW control. The SDW controls developed slight foliar tip chlorosis (mean severity rating of 1.31) that may have been caused by physiological stress (Fig. 1A; Table 3).

Pathogenicity tests on ginger rhizome slices. Toothpick inoculations with bacterial cells of fruit fly strain Dd-18 did not produce any disease symptoms on either mature or young ginger slices (data not shown). Mild symptoms (Fig. 1D; Table 2) were observed on mature, but not on young, ginger slices inoculated with ginger strains B193-3 and KN1-19 (13 to 19\% incidence). Infection incidences at the central cylinder or endodermal layer inoculation sites were not statistically different $(P>0.05)$.

In a separate experiment in which wounded ginger slices from young or mature rhizomes were inoculated at the central cylinder with liquid inoculum $\left(10^{6}\right.$, $10^{7}$, or $10^{8} \mathrm{CFU}$ per site), all concentrations were equally effective in producing rot symptoms but were not statistically different from SDW controls (Table 4). There were no significant differences $(P>$ $0.05)$ in incidences or severity ratings of rot symptoms among the three bacterial strains. The only main effect with means that were significantly different $(P<$ $0.001)$ was rhizome age. Incidences of infection and disease severity ratings were significantly higher in mature ginger slices than in young ginger slices (Table 4). Analysis of variance indicated no interaction among the main effects (bacterial concentration, rhizome age, and bacterial treatment).

Pathogenicity tests on ginger rhizome segments under low oxygen or aerobic conditions. Despite severe rotting symptoms and abundant gas $\left(\mathrm{CO}_{2}\right)$ that were produced under low oxygen storage conditions (Fig. 1E and F; Table 2), analysis of variance indicated no significant difference $(P=0.2772)$ in incidences of rot between inoculated ginger rhizome segments that were stored in vacuum-sealed bags or stored without bags (Fig. 1G; Table 5). There was no storage $\times$ bacterial treatment interaction. All three bacterial strains had significantly greater incidences $(P<0.05)$ of rot than the SDW control in the inocu- 
lated rhizome segments that were combined for storage treatment (Table 5). Rhizome segments inoculated with SDW and stored under low oxygen conditions developed discoloration or abnormal texture due to unknown causes, while the SDW controls stored under aerobic conditions did not develop symptoms (data not shown). E. cloacae was not isolated from the SDW controls that were stored under either low oxygen or aerobic conditions (three and four isolation attempts, respectively).

Pathogenicity tests on potted ginger plants in a greenhouse. No disease symptoms were produced on greenhouse-grown ginger plants inoculated at the root zone with bacteria or SDW (data not shown).

Pathogenicity tests on other hosts: papaya fruit. The three cultivars of papaya exhibited different degrees of susceptibility when inoculated with B193-3, KN1-19, and Dd-18. All three bacterial strains produced internal yellowing symptoms (Table 2) in 75 to $80 \%$ of 'Kapoho Solo' fruit (Fig. 2A, second, third, and fourth from left) and in 17 to $25 \%$ of 'Rainbow' fruit; no symptoms were produced in 'Sun Up' fruit (Table 6). None of the SDW controls produced disease symptoms (Fig. 2A, far left).

Pathogenicity tests on onion bulb. Internal rot symptoms were produced in 33 to $100 \%$ of the onion bulbs inoculated with B193-3, KN1-19, or Dd-18 (Fig. 2B, middle and right; Table 7). There were no rot symptoms in the SDW-inoculated controls (Fig. 2B, left). Overall, the rot symptoms in onion bulbs were mild, with the exception of KN1-19, which produced moderate symptoms (mean severity rating, 2.9) and incidence of $\operatorname{rot}(100 \%)$ that were significantly higher $(P<0.05)$ than the other strains and/or the SDW control (Table 7).

Reisolation of bacterial strains from inoculated plant hosts. Strains B193-3, KN1-19, and Dd-18 were reisolated and identified as E. cloacae on API 20E strips at least once and often several times from plant hosts that developed disease symptoms after inoculation with the respective bacterial strains, thereby fulfilling Koch's postulates and demonstrating pathogenicity. E. cloacae was not isolated from asymptomatic or symptomatic SDW controls. Rhizome quality of ginger slices and segments with symptomatic SDW controls was likely affected by other naturally occurring microorganisms (37).

\section{DISCUSSION}

Strains B193-3 and KN1-19 that were isolated from decayed ginger rhizomes were identified as E. cloacae (Jordan) Hormaeche \& Edwards based on bacteriological tests and molecular analysis. This is the first report of E. cloacae associated with a ginger rot, although the bacterium is associated with other plant diseases $(4,7,8,10,25-27,29,33,36,38)$.

The mucoid colony form of B193-3 differed from the nonmucoid colony form of KN1-19 and Dd-18, especially on media containing sugar carbohydrates (e.g., glucose in Kelman's medium). The importance of mucoid forms of E. cloacae is unknown, although EPS production may provide the bacterium with some protection in harsh environments (21), or may be a factor in causing wilt symptoms in other hosts (10). In our studies, there was no statistical difference in incidence or severity of symptoms on ginger between the mucoid and nonmucoid ginger strains (B193-3 and KN1-19, respectively), although on onion, symptoms were slightly more severe with KN1-19 than with B193-3.

Ginger strains B193-3 and KN1-19 produced severe rhizome and foliar symptoms on inoculated ginger plantlets in test tubes. The foliar "burning" and basal stem or rhizome rot symptoms of ginger plantlets were similar to symptoms of coconut root (wilt) disease, which is characterized by yellowing and marginal necrosis of leaves and a "defective root system" (10). E. cloacae was isolated from diseased coconut roots; however, its pathogenicity on coconut plants was not confirmed, although an aqueous extract of a polysaccharide substance of the bacterium produced wilt symptoms on tomato seedlings (10).

The in vitro pathogenicity tests with tissue-cultured ginger plantlets afforded a convenient bioassay using pathogen-free plants, and although not the same as using plants grown under soil conditions, the tests showed differences among the ginger and fruit fly strains. The symptoms exhibited by the ginger plantlets when inoculated with the ginger strains were severe compared with the significantly fewer and milder disease symptoms when inoculated with the fruit fly strain.

Strains B193-3, KN1-19, and Dd-18 differed in pathogenic responses to ginger and onion, but there were no strain differences on three papaya cultivars. The vary-

Table 3. Effect of inoculation ${ }^{\mathrm{u}}$ of wounded or nonwounded tissue-cultured ginger plantlets in test tubes with Enterobacter cloacae strains from ginger (B193-3, KN1-19) or fruit fly (Dd-18), or sterile distilled water (SDW) after about 14 days at $30^{\circ} \mathrm{C}$

\begin{tabular}{|c|c|c|c|c|c|c|}
\hline \multirow[b]{2}{*}{ Effect } & \multicolumn{2}{|c|}{$\%$ disease incidence $^{v}$} & \multicolumn{2}{|c|}{ Disease severity rating ${ }^{v, w}$} & \multicolumn{2}{|c|}{$\%$ dead plants ${ }^{v, x}$} \\
\hline & Rep. & Mean & Rep. & Mean & Rep. & Mean \\
\hline \multicolumn{7}{|l|}{ Inoculation method } \\
\hline Wounding & 8 & 62.5 & 4 & 2.69 & 8 & 18.8 \\
\hline Nonwounding & 16 & 54.7 & 12 & 2.83 & 16 & 28.1 \\
\hline \multicolumn{7}{|l|}{ Bacterial treatment } \\
\hline Enterobacter cloacae B193-3 & 6 & $95.8 \mathrm{a}^{\mathrm{y}}$ & 4 & $4.34 \mathrm{a}$ & 6 & $62.5 \mathrm{a}$ \\
\hline E. cloacae $\mathrm{KN} 1-19$ & 6 & $100.0 \mathrm{a}$ & 4 & $4.09 \mathrm{a}$ & 6 & $37.5 \mathrm{a}$ \\
\hline E. cloacae Dd-18 & 6 & $33.3 \mathrm{~b}$ & 4 & $1.44 \mathrm{~b}$ & 6 & $0.0 \mathrm{~b}$ \\
\hline \multirow[t]{2}{*}{ SDW control } & 6 & $0.0 \mathrm{c}$ & 4 & $1.31 \mathrm{~b}$ & 6 & $0.0 \mathrm{~b}$ \\
\hline & \multicolumn{6}{|c|}{ Analysis of variance } \\
\hline Source & $\mathrm{df}$ & $F$ value & df & $F$ value & $\mathrm{df}$ & $F$ value \\
\hline Inoculation method (I) & 1 & 0.00 & 1 & 2.81 & 1 & 0.50 \\
\hline Bacterial treatment $(\mathrm{T})$ & 3 & $17.33^{* * * \mathrm{z}}$ & 3 & $104.11^{* * * *}$ & 3 & $12.94^{* * *}$ \\
\hline Experiment & 3 & 1.64 & 2 & 1.43 & 3 & 0.67 \\
\hline $\mathrm{I} \times \mathrm{T}$ & 3 & 0.26 & 3 & 2.26 & 3 & $4.50^{*}$ \\
\hline \multicolumn{7}{|c|}{$\begin{array}{l}\text { u' Two to four plantlets were inoculated with } 0.5 \mathrm{ml} \text { of bacterial suspension }\left(10^{9} \mathrm{CFU} / \mathrm{ml}\right) \text { or SDW, then were incubated in a continuously illuminated (fluo- } \\
\text { rescent cool, daylight, } 15 \mathrm{~W} \text { ) incubator. }\end{array}$} \\
\hline \multicolumn{7}{|c|}{$\begin{array}{l}{ }^{\mathrm{V}} \text { Data were analyzed by the least squares means option of the generalized linear models procedure at } P=0.05 \text {. The experiment was conducted four times, } \\
\text { twice with both wounded and nonwounded plantlets, and twice with only nonwounded plantlets. Replicates consisted of two to four plantlets. Results are } \\
\text { presented as means instead of LSMeans. }\end{array}$} \\
\hline \multicolumn{7}{|c|}{$\begin{array}{l}\text { w Data represent disease severity rating based on a scale where } 1=\text { healthy (no symptoms), } 2=\text { slight (up to } 25 \% \text { ) foliar and/or rhizome/root symptoms, } 3= \\
\text { moderate (up to } 50 \% \text { ) foliar and/or rhizome/root symptoms, } 4=\text { severe (up to } 75 \% \text { ) foliar and/or rhizome/root rot symptoms, } 5=\text { dead plantlet. Disease } \\
\text { severity ratings were performed on three experiments. }\end{array}$} \\
\hline \multicolumn{7}{|c|}{${ }^{x}$ Data represent percent dead plantlets (mean disease severity rating of 4.5 to 5 on a scale of $1=$ healthy to $5=$ dead) } \\
\hline \multicolumn{7}{|c|}{$\begin{array}{l}\text { y Means in columns, by effect category, followed by the same letter are not significantly different according to the } t \text { test of least squares means of percent } \\
\text { disease incidence, disease severity rating, or percent dead plants at } P=0.05 \text {. }\end{array}$} \\
\hline
\end{tabular}


ing responses of Dd-18 on ginger (plantlets, slices, or segments) suggest either that Dd-18 is a weak pathogen of ginger or that ginger is a poor host for this strain. Other investigators reported no differences in pathogenicity among E. cloacae strains for onion (4) or papaya (27).

The failure to produce disease symptoms on ginger plants grown in pots under greenhouse conditions when inoculated with E. cloacae strains was unexpected because of our positive results in in vitro tests, and may be due to one or more of the following factors: (i) the young plants were not at a susceptible maturity (i.e., rhizome age was too young); (ii) temperature and relative humidity conditions were not optimal for infection; or (iii) aeration and low soil moisture were not conducive to infection (e.g., stagnant and waterlogged soil conditions may be needed for E. cloacae infection to occur). The first and last factors seem the most likely scenarios in the failure to obtain pathogenic responses on inoculated ginger plants in pots.

Mature tissues appear to be more susceptible to E. cloacae infection than young tissues. Infection rates in mature ginger slices were significantly higher $(P<0.05)$ than in young slices in inoculations with the three bacterial strains in the second ginger slice inoculation experiment (i.e., pipette inoculation). Variation in tissue maturity of young rhizomes may have accounted for the absence of symptoms in inoculated ginger slices in the first experiment (i.e., toothpick inoculation) (5month-old plants) and mild symptoms in the second experiment (7-month-old plants). Host or tissue maturity affecting susceptibility to $E$. cloacae infection was also reported by others. E. cloacae did not cause disease in young, growing onions, or in colorbreak and one-fourth-ripe papaya fruit, but it caused internal rot in mature onion bulbs (4) and internal yellowing infection in ripe papaya fruit $(26,27)$.

In our investigations, E. cloacae strains were isolated from both healthy and diseased ginger rhizomes. In diseased ginger, E. cloacae was isolated along with other bacteria, including $R$. solanacearum. We showed that when inoculated alone, $E$. cloacae produced disease symptoms on ginger, papaya fruit, and onion bulbs, indicating that E. cloacae may act independ-

Table 4. Effect of bacterial concentration and ginger rhizome age on percent incidence and severity rating of rot symptoms of wounded ginger slices inoculated ${ }^{\mathrm{V}}$ at the center of the central cylinder with strains of Enterobacter cloacae (B193-3, KN1-19, Dd-18) or sterile distilled water (SDW) after 12 to 14 days at $30^{\circ} \mathrm{C}$

\begin{tabular}{|c|c|c|c|}
\hline & & $\%$ incidence $^{w}$ & Severity rating ${ }^{\mathrm{w}, \mathrm{x}}$ \\
\hline Effect & Rep. & Mean & Mean \\
\hline \multicolumn{4}{|l|}{ Bacterial concentration } \\
\hline $0 \mathrm{CFU}$ & 12 & 25.00 & 1.75 \\
\hline $10^{6} \mathrm{CFU}$ & 12 & 50.00 & 2.03 \\
\hline $10^{7} \mathrm{CFU}$ & 12 & 35.42 & 1.92 \\
\hline $10^{8} \mathrm{CFU}$ & 12 & 39.58 & 2.06 \\
\hline \multicolumn{4}{|l|}{ Rhizome age } \\
\hline Mature & 24 & $59.38 \mathrm{a}^{\mathrm{y}}$ & $2.65 \mathrm{a}$ \\
\hline Young & 24 & $15.63 \mathrm{~b}$ & $1.23 \mathrm{~b}$ \\
\hline \multicolumn{4}{|l|}{ Bacterial treatment } \\
\hline E. cloacae B193-3 & 16 & 48.44 & 2.12 \\
\hline E. cloacae $\mathrm{KN}$ 1-19 & 16 & 31.25 & 1.96 \\
\hline E. cloacae Dd-18 & 16 & 32.81 & 1.74 \\
\hline \multicolumn{4}{|l|}{ Experiment } \\
\hline Test 1 & 24 & $46.88 \mathrm{a}$ & $2.36 \mathrm{a}$ \\
\hline \multirow[t]{2}{*}{ Test 2} & 24 & $28.13 b$ & $1.52 \mathrm{~b}$ \\
\hline & & Analysis of variance & \\
\hline Source & $\mathrm{df}$ & $F$ value & $F$ value \\
\hline Bacterial concentration (C) & 3 & 1.30 & 0.33 \\
\hline Rhizome age (A) & 1 & $23.32^{* * *} \mathrm{z}$ & $33.23^{* * *}$ \\
\hline Bacterial treatment $(\mathrm{T})$ & 2 & 1.47 & 0.79 \\
\hline Experiment & 1 & $4.28^{*}$ & $11.75^{* *}$ \\
\hline $\mathrm{C} \times \mathrm{A}$ & 3 & 0.93 & 0.53 \\
\hline $\mathrm{T} \times \mathrm{C}$ & 6 & 0.50 & 0.28 \\
\hline $\mathrm{T} \times \mathrm{A}$ & 2 & 0.36 & 0.09 \\
\hline $\mathrm{T} \times \mathrm{C} \times \mathrm{A}$ & 6 & 0.13 & 0.27 \\
\hline
\end{tabular}

${ }^{\mathrm{v}}$ Four ginger slices of mature or young rhizome maturity per concentration were inoculated at the center with $100 \mu \mathrm{l}$ of cell suspension or SDW (0 CFU).

${ }^{w}$ Data were analyzed by GLM procedure. The experiment was repeated once. Replicates consisted of four ginger slices. Results are presented as means instead of LSMeans.

${ }^{\mathrm{x}}$ Data represent severity ratings of rot symptoms of ginger slices based on $1=$ healthy tissue, $2=$ slight (up to 25\%) rot (slight discoloration), $3=$ moderate (up to 50\%) rot (discoloration and tissue breakdown), $4=$ severe rot ( 50 to $75 \%$ of slice affected), and $5=$ complete rot (up to entire slice affected).

${ }^{y}$ Means (same as LSMeans) in columns, by effect category, followed by the same letter are not significantly different according to the $t$ test of least squares means of percent incidence or disease rating at $P=0.05$.

$\mathrm{z} *,{ }^{* *},{ }^{* * *} F$ value for effect significant at $P=0.05, P=0.01$, or $P=0.001$, respectively. ently under certain conditions (e.g., host susceptibility), but at the same time, may also depend on physiological and biological factors in the host-pathogen (or hostmicroflora) complex for disease expression, demonstrating the opportunistic nature of this bacterium.

The occurrence of E. cloacae as an opportunistic pathogen has been observed in other hosts. E. cloacae or Enterobacter spp. were isolated alone, or with other bacterial strains from diseased onion bulbs with internal rot $(4,8)$, from healthy and diseased watermelons with watermelon rind necrosis (12), and from bacterial leaf rot of Odontioda orchids (36). These studies concluded that E. cloacae and other bacteria are part of the natural microflora of both the host and the environment, and may become opportunistic pathogens under certain environmental and/or physiological conditions that favor the bacteria or cause the host to become susceptible to infection. Some of the reported environmental conditions included high temperatures (35 to $37^{\circ} \mathrm{C}$ ) and high humidity. Similar observations, including isolation of several bacterial strains, difficulty in reproducing symptoms, and symptom development requiring moisture, were encountered by Kaneshiro et al. (16) when they studied the relationship between E. clo-

Table 5. Effect of storage in vacuum-sealed bags on percent incidence of rot symptoms of ginger rhizome segments inoculated ${ }^{\mathrm{w}}$ with strains of Enterobacter cloacae (B193-3, KN119, Dd-18) or sterile distilled water (SDW) control after 6 to 8 days at $30^{\circ} \mathrm{C}$

\begin{tabular}{|c|c|c|}
\hline \multirow[b]{2}{*}{ Effect } & \multicolumn{2}{|c|}{$\%$ incidence $^{\mathrm{x}}$} \\
\hline & Rep. & Mean \\
\hline \multicolumn{3}{|l|}{ Storage treatment } \\
\hline Vacuum-sealed & 12 & 42.29 \\
\hline Not vacuum- & 12 & 34.26 \\
\hline \multicolumn{3}{|l|}{ Bacterial treatment } \\
\hline E. cloacae B193-3 & 6 & $53.05 \mathrm{a}^{\mathrm{y}}$ \\
\hline E. cloc & 6 & $48.45 \mathrm{a}$ \\
\hline E. cloac & 6 & $46.83 \mathrm{a}$ \\
\hline SDW control & 6 & $4.77 \mathrm{~b}$ \\
\hline & \multicolumn{2}{|c|}{ Analysis of variance } \\
\hline Source & $\mathrm{df}$ & $F$ value \\
\hline Stora & 1 & \\
\hline Bacte & 3 & $10.02^{* * * z_{z}}$ \\
\hline Experiment & 2 & 1.40 \\
\hline $\mathrm{S} \times \mathrm{T}$ & 3 & 1.02 \\
\hline \multicolumn{3}{|c|}{$\begin{array}{l}{ }^{\text {w }} \text { Young to recently matured ginger rhizome } \\
\text { segments were inoculated by injecting ap- } \\
\text { proximately } 0.3 \mathrm{ml} \text { at one to three sites with } \\
\text { the same bacterial strain (cell suspension at } \\
10^{9} \mathrm{CFU} / \mathrm{ml} \text { ) or SDW, then covered with tape. } \\
\text { x Percent incidence of inoculated sites with rot } \\
\text { symptoms were analyzed by generalized linear } \\
\text { models procedure. The experiment was con- } \\
\text { ducted three times. Replicates consisted of at } \\
\text { least five inoculated sites for each bacterial } \\
\text { treatment per vacuum-seal storage treatment. }\end{array}$} \\
\hline
\end{tabular}


acae and gray kernel disease of macadamia nut.

The presence of E. cloacae in the internal tissue of apparently healthy ginger rhizomes may impact rhizome quality if storage conditions enhance bacterial growth and/or favor the development of decay. This was demonstrated in our studies with noninoculated and inoculated ginger rhizomes stored in vacuum-sealed bags.

In a preliminary study (not published), mature ginger rhizomes produced from tissue-cultured starter plantlets that were free of $R$. solanacearum were stored under either low oxygen or aerobic environments at 22 or $4^{\circ} \mathrm{C}$. After 63 days of storage, vacuum-sealed bags stored at $22^{\circ} \mathrm{C}$ were inflated from gas production $\left(85 \% \mathrm{CO}_{2}\right.$, $0 \% \mathrm{O}_{2}$ ) and ginger rhizomes were flaccid, collapsed, stringy, and foul smelling, whereas the rhizomes stored at $4{ }^{\circ} \mathrm{C}$ were in good (marketable) condition. E. cloacae was isolated from two out of three juice or tissue samples collected from the decayed rhizomes. Our current study corroborated these results by inoculating commercial ginger segments with B193-3, KN1-19, and Dd-18, and reproducing similar rot symptoms under low oxygen storage conditions (i.e., vacuum-sealed bags) at $30^{\circ} \mathrm{C}$ for 6 to 8 days. The results illustrate the potential damaging effects of E. cloacae on ginger rhizome quality under high temperature and low oxygen storage conditions, and serve as a caution in the use of modified atmosphere packaging that may enhance the growth of microorganisms or favor certain groups of microorganisms when $\mathrm{CO}_{2}$ levels are elevated (or $\mathrm{O}_{2}$ levels are reduced) (5).

We conclude that E. cloacae is an opportunistic pathogen of edible ginger that
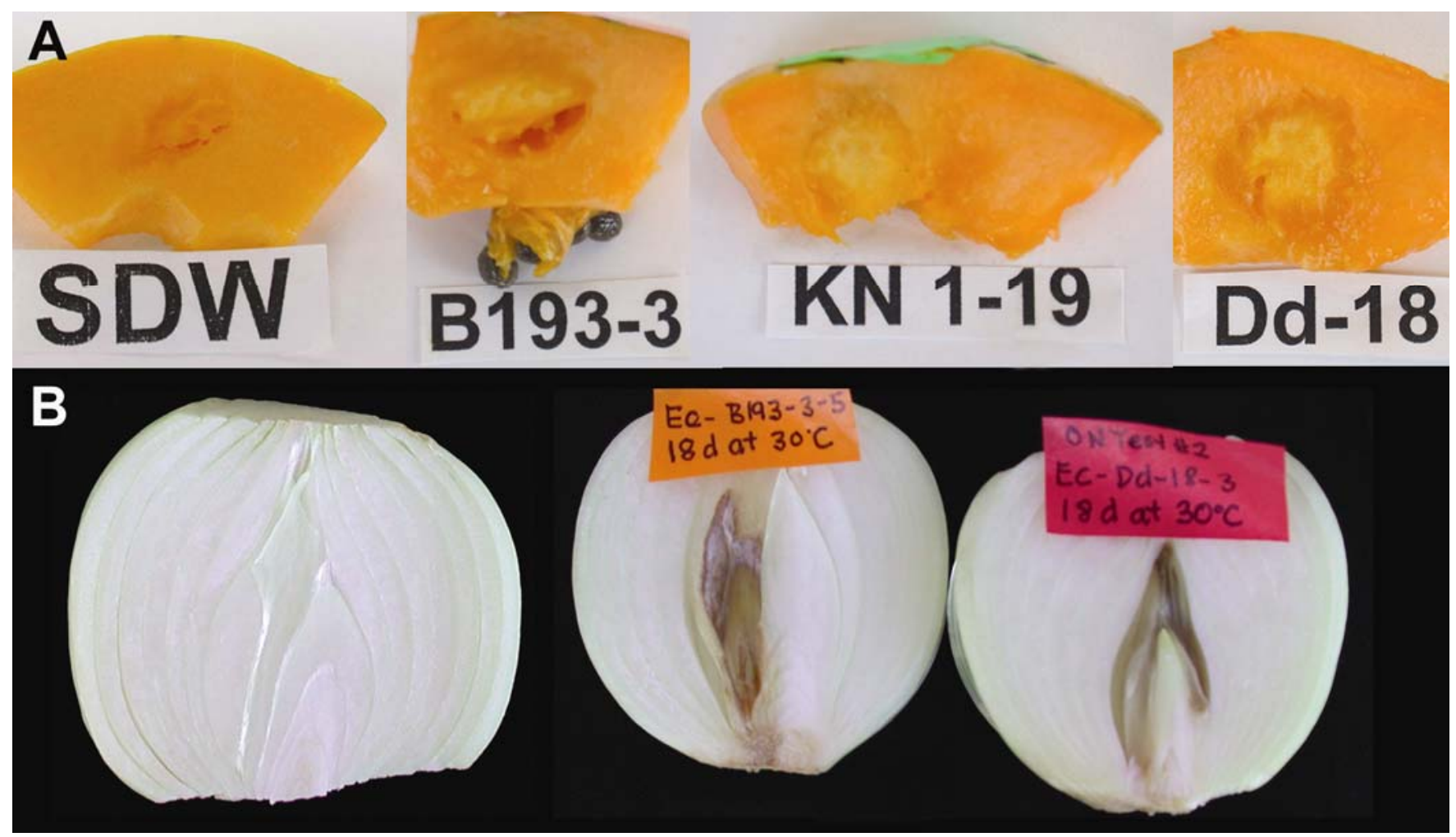

Fig. 2. Internal yellowing of papaya or internal rot of onion caused by Enterobacter cloacae. A, left to right, 'Kapoho Solo' papaya fruit treated with sterile distilled water (SDW) (far left), B193-3 (second from left), KN 1-19 (third from left), and Dd-18 (far right), after 4 to 5 days at 23 to $28^{\circ} \mathrm{C}$. B, left to right, Yellow onion bulbs inoculated with SDW (left), B193-3 (middle), and Dd-18 (right), after 11 to 18 days at $30^{\circ} \mathrm{C}$.

Table 6. Percent incidence of internal yellowing symptoms in papaya fruit ('Kapoho Solo', 'Rainbow', and 'Sun Up') inoculated ${ }^{\mathrm{w}}$ with strains of Enterobacter cloacae (B193-3, KN1-19, Dd-18) or sterile distilled water (SDW) and incubated at 23 to $28^{\circ} \mathrm{C}$ for 3 to 5 days

\begin{tabular}{|c|c|c|c|c|c|c|}
\hline \multirow[b]{3}{*}{ Effect } & \multicolumn{6}{|c|}{$\%$ incidence $^{x}$} \\
\hline & \multicolumn{2}{|c|}{ 'Kapoho Solo' } & \multicolumn{2}{|c|}{ 'Rainbow' } & \multicolumn{2}{|c|}{ 'Sun-Up' } \\
\hline & Exp. & Mean & Exp. & Mean & Exp. & Mean \\
\hline \multicolumn{7}{|l|}{ Bacterial treatment } \\
\hline E. cloacae B193-3 & 3 & $76.9 \mathrm{a}^{\mathrm{y}}$ & 3 & 20.1 & 2 & 0 \\
\hline E. cloacae KN1-19 & 2 & $80.0 \mathrm{a}$ & 2 & 25.0 & 2 & 0 \\
\hline E. cloacae Dd-18 & 3 & $75.2 \mathrm{a}$ & 3 & 16.8 & 2 & 0 \\
\hline SDW control & 3 & $0.0 \mathrm{~b}$ & 3 & 0.0 & 2 & 0 \\
\hline & \multicolumn{6}{|c|}{ Analysis of variance } \\
\hline Source & $\mathrm{df}$ & $F$ value & $\mathrm{df}$ & $F$ value & $\mathrm{df}$ & $F$ value \\
\hline Bacterial treatment & 3 & $190.07^{* * * z}$ & 3 & 3.39 & 3 & $\ldots$ \\
\hline Experiment & 2 & 1.90 & 2 & $6.09^{*}$ & 1 & $\ldots$ \\
\hline
\end{tabular}

${ }^{\mathrm{w}}$ Fruit of one-half to three-quarters ripeness stage were inoculated with $0.5 \mathrm{ml}$ of $10^{8}$ to $10^{9} \mathrm{CFU} / \mathrm{ml}$ of bacterial suspension of each strain or SDW at separate sites on the same fruit. Inoculated fruit (16 to 23 per experiment for 'Kapoho Solo' and 20 per experiment for 'Rainbow' or 'Sun Up') were incubated until completely ripe.

${ }^{x}$ Data for each cultivar were analyzed by the generalized linear models (GLM) procedure at $P=0.05$. Experiments were conducted at least twice. Results are presented as means instead of LSMeans.

${ }^{y}$ Means in columns followed by the same letter are not significantly different according to the $t$ test of the least squares means of percent incidence at $P=0.05$.

$\mathrm{z} *,{ }^{* * *} F$ value for effect significant at $P=0.05$ or $P=0.001$, respectively. 
Table 7. Percent incidence and severity rating of internal rot of yellow onion bulbs inoculated ${ }^{\mathrm{w}}$ with strains of Enterobacter cloacae (B193-3, KN1-19, and Dd-18) or sterile distilled water (SDW) after incubation at $30^{\circ} \mathrm{C}$ for 18 days

\begin{tabular}{|c|c|c|c|}
\hline \multirow[b]{2}{*}{ Treatment } & \multicolumn{2}{|c|}{$\%$ incidence $^{x}$} & \multirow{2}{*}{$\frac{\text { Disease severity rating }}{\text { Mean }}$} \\
\hline & Exp. & Mean & \\
\hline \multicolumn{4}{|l|}{ E. cloacae } \\
\hline B193-3 & 2 & $50.0 \mathrm{ab}^{\mathrm{z}}$ & $1.70 \mathrm{~b}$ \\
\hline KN1-19 & 2 & $100.0 \mathrm{a}$ & $2.85 \mathrm{a}$ \\
\hline Dd-18 & 2 & $32.5 \mathrm{~b}$ & $1.65 \mathrm{~b}$ \\
\hline SDW control & 2 & $0.0 \mathrm{~b}$ & $1.00 \mathrm{~b}$ \\
\hline
\end{tabular}

${ }^{\mathrm{w}}$ Mature onion bulbs were inoculated at the stem-end with approximately $0.5 \mathrm{ml}$ of $10^{9} \mathrm{CFU} / \mathrm{ml}$ bacterial suspension or SDW. Inoculated bulbs (four to five per treatment) were stored individually in Ziploc type plastic storage bags.

${ }^{x}$ Data were transformed (arcsine-square root) for analysis by GLM procedure then retransformed for presentation (34). The experiment was conducted twice.

y Severity of rot symptoms was based on a ratings scale where $1=$ healthy, $2=$ slight (up to $25 \%$ discolored or flaccid tissue), $3=$ moderate (up to $50 \%$ internal tissue discolored and flaccid), $4=$ severe ( 50 to $75 \%$ of bulb affected), and $5=$ complete (up to entire bulb affected).

${ }^{\mathrm{z}}$ Means in columns followed by the same letter(s) are not significantly different according to the LSD test at $P=0.05$.

can cause rot symptoms in rhizomes and enhanced foliar burning symptoms in ginger plants under conditions that favor bacterial growth or host susceptibility. We believe E. cloacae can exist as an endophyte in healthy ginger rhizomes, similar to its occurrence in other monocots such as corn $(3,11)$, rice $(18)$, and sugarcane (23). However, in mature ginger, when certain environmental conditions such as high temperature, high relative humidity, and low oxygen atmospheres are present, the bacterium may attain high populations and produce disease symptoms.

Within the limited number of hosts we tested for pathogenicity, ginger appears to be less susceptible to rot than papaya fruit. Interestingly, different papaya cultivars showed varied levels of susceptibility to the three E. cloacae strains, ranging from susceptible by 'Kapoho Solo' to immune by 'Sun Up'. 'Rainbow', an F1 hybrid between 'Kapoho' and 'Sun Up', exhibited an intermediate level of resistance compared with the two parental lines. Therefore, genetic factors also may determine host susceptibility to E. cloacae infection. This is an area of investigation that deserves further study. The interactions of $E$. cloacae with other bacteria (e.g., R. solanacearum) in the microflora of ginger also merit further investigation.

\section{ACKNOWLEDGMENTS}

We acknowledge the following individuals who contributed in various ways to this paper: Claire Arakawa (tissue-cultured plantlets), Russell Kai (greenhouse ginger plants and supplies), Koji Okamura (papaya fruit), Trevor Gentry and Sandra Silva (gas analysis in vacuum-sealed storage bags), Paul Moore (suggestion on 'Sun Up' papaya inoculations), Robyn Fukamizu (student help), Jean Doherty (student help), and Paul Barr (computer technology). We also thank the reviewers of this manuscript.

\section{LITERATURE CITED}

1. Altschul, S. F., Madden, T. L., Schaffer, A. A., Zhang, J., Zhang, Z., Miller, W., and Lipman, D. J. 1997. Gapped BLAST and PSI-BLAST: A new generation of protein database search programs. Nucleic Acids Res. 25:3389-3402.
2. Atlas, R. M. 1993. Peptone Yeast Extract Medium. Page 704 in: Handbook of Microbiological Media. L. C. Parks, ed. CRC Press, Boca Raton, FL.

3. Bacon, C. W., and Hinton, D. M. 1993. Endophytic nature of Enterobacter cloacae in roots of corn seedlings. (Abstr.) Phytopathology 83:1406.

4. Bishop, A. L., and Davis, R. M. 1990. Internal decay of onions caused by Enterobacter cloacae. Plant Dis. 74:692-694.

5. Brackett, R. E., and Splittstoesser, D. F. 2001. Fruits and Vegetables. Chapter 50. Pages 515520 in: Compendium of Methods for the Microbiological Examination of Foods, 4th ed. F. P. Downes and K. Ito, eds. American Public Health Association, Washington, DC.

6. Brenner, D. J., McWhorter, A. C., Kai, Akemi, Steigerwalt, A. G., and Farmer, J. J., III. 1986. Enterobacter asburiae sp. nov., a new species found in clinical specimens, and reassignment of Erwinia dissolvens and Erwinia nimipressuralis to the genus Enterobacter as Enterobacter dissolvens comb. nov. and Enterobacter nimipressuralis comb. nov. J. Clin. Microbiol. 23:1114-1120.

7. Carter, J. C. 1945. Wetwood of elms. Ill. Nat. Hist. Surv. Bull. 23:407-448.

8. Cother, E. J., and Dowling, V. 1986. Bacteria associated with internal breakdown of onion bulbs and their possible role in disease expression. Plant Pathol. 35:329-336.

9. Ewing, W. H., Davis, B. R., and Reavis, R. W. 1957. Phenylalanine and malonate media and their use in enteric bacteriology. Public Health Lab. 15:153-167.

10. George, M., Potty, V. P., and Jayasankar, N. P. 1976. Association of Enterobacter with coconut root (wilt) disease. Curr. Sci. 45(18):677678.

11. Hinton, D. M., and Bacon, C. W. 1995. Enterobacter cloacae is an endophytic symbiont of corn. Mycopathologia 129:117-125.

12. Hopkins, D. L., and Elmstrom, G. W. 1977. Etiology of watermelon rind necrosis. Phytopathology 67:961-964.

13. Hugh, R., and Leifson, E. 1953. The taxonomic significance of fermentative versus oxidative metabolism of carbohydrates by various Gram negative bacteria. J. Bacteriol. 66:24-26.

14. Ishii, M., and Aragaki, M. 1963. Ginger wilt caused by Pseudomonas solanacearum E. F. Smith. Plant Dis. Rep. 47:710-713.

15. Jang, E. B., and Nishijima, K. A. 1990. Identification and attractancy of bacteria associated with Dacus dorsalis (Diptera: Tephritidae). Environ. Entomol. 19(6):1726-1731.

16. Kaneshiro, W. S., Cavaletto, C. G., Tang, C. S., and Alvarez, A. M. 2003. Gray kernel disease of macadamia nut: Are bacteria involved? Online publication. Plant Health Progress doi:10.1094/PHP-2003-0825-01-HN.

17. Kelman, A. 1954. The relationship of pathogenicity in Pseudomonas solanacearum to colony appearance on a tetrazolium medium. Phytopathology 44:693-695.

18. Ladha, J. K., Barraquio, W. L., and Watanabe, I. 1983. Isolation and identification of nitrogen-fixing Enterobacter cloacae and Klebsiella planticola associated with rice plants. Can. J. Microbiol. 29:1301-1308.

19. Marchini, D., Rosetto, M., Dallai, R., and Marri, L. 2002. Bacteria associated with the oesophageal bulb of the medfly Ceratitis capitata (Diptera:Tephritidae). Curr. Microbiol. 44:120-124.

20. Martin, D. A. 2002. Hawaii ginger root. Hawaii Agric. Stat. Serv. August 8, 2002. Hawaii Dept. Agriculture, Honolulu, HI.

21. Mead, M. J., Nakas, J. P., and Tanenbaum S. W. 1993. Highly viscous polysaccharide produced by an Enterobacter isolate on a hemicellulose hydrolysate. Biotechnol. Lett. 15(4) 389-392.

22. Miller, T. D., and Schroth, M. N. 1972. Monitoring the ephiphytic population of Erwinia amylovora on pear with a selective medium. Phytopathology 62:1175-1182.

23. Mirza, M. S., Ahmad, W., Latif, F., Haurat, J., Bally, R., Normand, P., and Malik, K. A. 2001. Isolation, partial characterization, and the effect of plant growth-promoting bacteria (PGPB) on micro-propagated sugarcane in $v i$ tro. Plant Soil 237(1):47-54.

24. Murashige, T., and Skoog, F. 1962. A revised medium for rapid growth and bioassays with tobacco culture. Physiol. Plant 15:473-497.

25. Murdoch, C. W., and Campana, R. J. 1983. Bacteria species associated with wetwood of elm. Phytopathology 73:1270-1273.

26. Nishijima, K. A. 1994. Papaya Diseases Caused by Bacteria. Internal Yellowing. Page 65 in: Compendium of Tropical Fruit Diseases. R. C. Ploetz, G. A. Zentmyer, W. T. Nishijima, K. G. Rohrbach, and H. D. Ohr, eds. American Phytopathological Society, St. Paul, MN

27. Nishijima, K. A., Couey, H. M., and Alvarez, A. M. 1987. Internal yellowing, a bacterial disease of papaya fruits caused by Enterobac ter cloacae. Plant Dis. 71:1029-1034.

28. Richard, C. 1984. Genus VI. Enterobacter Hormaeche and Edwards 1960, 72; Nom. Cons. Opin. 28, Jud. Comm. 1963, 38. Pages 465-469 in: Bergey's Manual of Systemic Bacteriology. Vol. 1. N. R. Kreig and J. G. Holt, eds. Williams \& Wilkins, Baltimore, MD.

29. Rosen, H. R. 1922. The bacterial pathogen of corn stalk rot. Phytopathology 12:497-499.

30. Rossiter, M. C., Howard, D. J., and Bush, G. L. 1983. Symbiotic bacteria of Rhagoletis pomonella. Pages 77-84 in: Fruit Flies of Economic Importance. R. Cavalloro, ed. A. A. Balkema, Rotterdam.

31. Sanders, W. E., and Sanders, C. C. 1997 Enterobacter spp.: Pathogens poised to flourish at the turn of the century. Clin. Microbiol. Rev. 10:220-241.

32. Schaad, N. W. 1988. I. Initial Identification of Common Genera. Pages 1-15 in: Laboratory Guide for the Identification of Plant Pathogenic Bacteria, 2nd ed. N. W. Schaad, ed. American Phytopathological Society, St. Paul MN.

33. Schwartz, H. F., and Otto, K. 2000. First report of a bulb decay of onion by Enterobacter cloacae in Colorado. Plant Dis. 84:808.

34. Snedecor, G. W., and Cochran, W. G. 1989. Statistical Methods, 8th ed. Iowa State University, Ames.

35. Sutton, D. D., Ark, P. A., and Starr, M. P. 1960. The causal agent of bacterial brown rot of $\mathrm{Cy}$ - 
pripedium orchids. Phytopathology 50:182-186.

36. Takahashi, Y., Takahashi, K., Sato, M., Watanabe, K., and Kawano, T. 1997. Bacterial leaf rot of Odontioda orchids caused by Enterobacter cloacae. Ann. Phytopathol. Soc. Jpn. 63:164-169.
37. Trujillo, E. E. 1964. Diseases of Ginger (Zingiber officinale) in Hawaii. Circ. 62. Hawaii Agricultural Experiment Station, University of Hawaii at Manoa.

38. Wick, R. L., Rane, K. K., and Sutton, D. K. 1987. Mung bean sprout disease caused by Enterobacter cloacae. (Abstr.) Phytopathology 77:123.

39. Young, J. P. W., Downer, H. L., and Eardly, B. D. 1991. Phylogeny of the phototrophic Rhizobium strain BTAil by polymerase chain reaction-based sequencing of a 16S rRNA gene segment. J. Bacteriol. 173:2271-2277. 